\title{
Indonesian Hotels' Dynamic Capability under the Risks of COVID-19
}

\author{
Muhammad Yunus Amar ${ }^{1, *}$, Alim Syariati ${ }^{2}$ (D), Ridwan Ridwan ${ }^{3}$ and Rika Dwi Ayu Parmitasari ${ }^{2}$ \\ 1 Management Department, Universitas Hasanuddin, Makassar 90245, Indonesia \\ 2 Management Department, Universitas Islam Negeri Alauddin Makassar, Gowa 92118, Indonesia; \\ alim.syariati@uin-alauddin.ac.id (A.S.); rparmitasari@uin-alauddin.ac.id (R.D.A.P.) \\ 3 Economics Department, Universitas Janabadra, Yogyakarta 55271, Indonesia; ridwan@janabadra.ac.id \\ * Correspondence: myunmar@unhas.ac.id
}

Citation: Amar, Muhammad Yunus, Alim Syariati, Ridwan Ridwan, and Rika Dwi Ayu Parmitasari. 2021. Indonesian Hotels' Dynamic Capability under the Risks of COVID-19. Risks 9: 194. https:// doi.org/10.3390/risks9110194

Academic Editor:

Zbysław Dobrowolski

Received: 16 September 2021

Accepted: 28 October 2021

Published: 3 November 2021

Publisher's Note: MDPI stays neutral with regard to jurisdictional claims in published maps and institutional affiliations.

Copyright: (c) 2021 by the authors. Licensee MDPI, Basel, Switzerland. This article is an open access article distributed under the terms and conditions of the Creative Commons Attribution (CC BY) license (https:// creativecommons.org/licenses/by/ $4.0 /)$.

\begin{abstract}
The effects of COVID-19 on tourism are irreversible, with potential reductions in income, job losses, shifting working landscapes, and visible health-related fears. These adversities are reinforced in the hospitality business, particularly for hotels, the income streams of which rely on individual movements. This study investigates the process undertaken by the hotel industry in Indonesia to face the current challenges, particularly in terms of the dynamic capabilities possessed by hotel businesses. This construct discusses the potentiality of maximizing existing resources and its impact on innovation norms to leverage hotel dynamics. A total of 329 hotel managers responded to the survey, and the data were finalized by employing PLS-SEM. The findings primarily support the hypothesized direct relationships, but refute the presence of indirect relationships. The results amplify how past investments in sustainable resources are easily deployed assets during COVID-19 and create a welcoming environment for dynamic innovation among hotels during periods of change.
\end{abstract}

Keywords: dynamic capability; existing resources; innovation norms; hotel; strategy; Indonesia

\section{Introduction}

As the COVID-19 pandemic has spread worldwide, new business practices have been developed, particularly in the hotel industry. Individual movements in public spaces have been partially or entirely restricted, resulting in a significant reduction in hotel occupancy. In some scenarios, McKinsey reports an estimated decline in growth of 20\% through 2023. Research in Europe indicates the negative impact on essential tourist destinations (Napierała et al. 2020). It is reinforced by data from the hospitality business in China and Indonesia (Rahma and Arvianti 2020). Indonesia records a $12.6 \%$ decrease in Y.o.Y. occupancy rates from international tourists, with an estimated USD 6 billion lost only in the first half of 2020 (statista.com, accessed on 20 October 2021). The Indonesia Ministry of Tourism mentioned that 400 thousand people have become unemployed, with 900 thousand workers being temporarily laid off, while 12.91 million have had their working hours decreased (Ministry of Tourism Press Release). These negativities create extreme environmental pressure on businesses, and thus require immediate managerial actions.

Some studies have highlighted the success and failure factors in combating COVID-19. Early risk management strategies advocate the importance of strict government in imposing restrictions or lockdowns, as evidenced by some Asia-Pacific countries (Ling et al. 2021; Şahin et al. 2020). Other studies insisted on the importance of testing and tracking in countries in decreasing the spread of the virus (Dobrowolski 2021; Marcel et al. 2020). On the contrary, strict lockdowns lead to country-wide economic damage. Thus, a strategic approach towards the pandemic was proposed, which involves the partial lifting of restrictions to create herd immunity (de Vlas and Coffeng 2021). Despite higher mortality rates, this policy was found to accelerate the country's recovery (Chancharoenthana et al. 2021). 
The implementation of this plan requires an extensive fund allocation to meet the associated public health costs, such as hospital beds, oxygen ventilators, filtered air conditioners, vaccination rollouts, and human resources (Coccia 2022). Despite the debates surrounding this approach, the risk communication strategy must be perceived and transmitted to every community in an ongoing process (Adebisi et al. 2021). It is worth noting that decisive leadership, which can undertake strategic action amid the pressure of this pandemic, is crucial (Al Saidi et al. 2020; Drozdowski et al. 2021). We argue that possessing integrated dynamic capability (D.C.) is critical for hospitality business during adversity, but requires several prerequisite foundations, i.e., existing resources and innovation norms within the organization.

Teece et al. (1997) introduced D.C. as a strategic management theory. It has attracted academics and practitioners who have attempted to dissect this concept (GutierrezGutierrez and Antony 2020). Hoskisson et al. (1999) position this approach as a balancing of the contrasting perspectives of proponents of external (Porter 1979) and internal views (Wernerfelt 1984). It focuses on strengthening the internal capacity for environmental opportunities and challenges. It is a loose concept. Authors have described D.C. as an information system (Talafidaryani 2021) and also in terms of sustainability (Amui et al. 2017), big data savviness (Rialti et al. 2019), innovation (Hanchi and Kerzazi 2020), and other extensive applications. Researchers have expressed critiques regarding its theoretical basis and suggest a focus on other existing, more established theories that have been tested theoretically (Arend and Bromiley 2009). Zahra et al. (2006) stated some problems with the conceptualization of D.C. First, there is no agreement on whether D.C. is the company's ability to deal with various changes or whether D.C. is the company's ability to make changes in response to business shocks. Second, the combination of internal and external factors in observations can be confusing when analyzing resource changes. However, they argue that D.C. can fill the gap in transformations, where various strategic steps are employed to respond to the shifting business landscape. The context of COVID-19 presents an environmental revolution and, arguably, is in line with the theory.

Operationalizing D.C. requires specific resources; furthermore, maximizing existing resources is the most visible strategy during a crisis, as generating fresh income, funds, and investment is constrained (Fukawa et al. 2021). The capacity of hotels to expand into multiple strands of business, redesign their offered products, employ digital approaches, and respond to market upheaval are four critical factors related to curbing the pandemicrelated economic problems in China (Hao et al. 2020). Strategic resources such as cognitive, emotional, and structural resources must be preserved in critical times (Richtnér and Löfsten 2014). This literature review serves as the reasoning for this study's investigation of the dynamic approach to essential resources, i.e., hotels' technological support and infrastructures (Lee et al. 2009). These resources would enhance the innovative capacity of firms in times of turbulence (Schweitzer et al. 2011). Hotels must reinforce innovation to capture precise customer responses, especially during COVID-19 (Díaz and Duque 2021).

This study investigated a seemingly neglected issue in the interaction of resources, innovation, and dynamic capability in the context of the COVID-19 crisis. We propose that technological support and infrastructure can be approached as existing and manageable resources from past investments. The supporting environments of hotels represent innovation norms and require awareness in seeking out new business endeavors. These constructs create direct and indirect relationships, leading to dynamic capability. This study contributes to the strategic management conversation in the hospitality business in Indonesia during global turbulence.

Helfat and Peteraf (2009) define dynamic capability (D.C.) as an organization's capacity to intentionally create, expand, and modify its resource base, whether tangible, intangible, or human assets with which the organization is in control can be accessed at any time. Hoskisson et al. (1999) stated this concept as a connector between two contradicting schools of thought in strategic management, the internal and external paradigms. Other academics propose it as a collective activity pattern by which organizations systematically create 
and modify operating routines to achieve increased organizational effectiveness (Zollo and Winter 2002). The company can reconfigure the company's resources and practices according to a shared pattern and is considered necessary by the highest decision-makers. However, they also remind that companies' strategy is not to rely solely on it alone, as it does not necessarily result in superior financial performance. Eisenhardt and Martin (2000) define it as the company's process of using resources-particularly integrating, configuring, acquiring, and releasing resources-to achieve or even create market change.

The last definition marks the connection between this strategic course and the current COVID-19 agenda. As it creates massive turbulence, especially in the hospitality business, the possession of dynamic management to maximize previous resources and enhance them to tone down the challenges is inevitable. A study on technological firms suggests building a creative intensity environment as a dynamic open-source firm (Fukawa et al. 2021). In the open innovation era, the capacity to shape the existing knowledge and use it to sense and seize the opportunity is mandatory (Patrício et al. 2021). In a time of dire condition, the government's support may facilitate a better knowledge in the dynamic capabilities possessions as an effort to increase the economic outcome (Liu 2021). The capacity of previous technological controls may leverage the recovery position of the hotel and be more dynamic under the turbulence of COVID-19 (Liu and Yang 2021). The resourcebased view theory (R.B.V.), the seminal work of Birger Wernerfelt (Wernerfelt 1984), was first introduced as the contender to Michael Porter's preposition of an externally focused strategy. Initially, the inspiration came from Chester Barnard in 1983, Philip Selznick in 1959, or Edith Penrose in 1959 (Hoskisson et al. 1999). This theory focused on the effort to possess strategic resources capable of creating a hard-to-get advantage over competitors. The possession of hard-to-imitate human resources, skills, and marketing would be the key to achieving distinctive competencies, leading to competitiveness (Eden and Ackermann 2000; Cappelli and Crocker-Hefter 1996; Smart and Conant 2011). Barney $(1991,2001)$ divided excellent resources into a range of characteristics, such as valuable, rare, inimitable, and non-substitutable. In the context of the hotel business, the potential of excellent resources is visible in terms of room cleanliness, the professional appearance of employees, and other competitive internal and service offers (Choi and Chu 2001).

In the context of COVID-19, hotels must be able to elaborate their existing resources to the maximum, as fresh investments are potentially unprobable (Fukawa et al. 2021). This study proposes the technological support (Ray et al. 2004) and hotel infrastructure (Choi and Chu 2001) are the past capacity possessions that can be established to support hotel innovation norms and dynamic capability. Technical support is indispensable in changing business (Powell and Dent-Micallef 1997). It serves as the foundation for creating innovative organizational norms, necessitating its place in digital transformation (Gurbaxani and Dunkle 2019). However, previous studies discussing the potential relationships between hotels' technological support and supportive environment are still inadequate, providing possible discussions in the field.

\section{Hypotheses}

Studies have deduced that data-driven firms successfully encourage the innovative culture, be it in process or product, supporting the role of upgraded technology in the business environment (Chatterjee et al. 2021; Ponciano and Amaral 2021) and further amplified in the e-businesses (Soto-Acosta et al. 2016). Technology also creates the foundation to be aware of potential opportunities. It presents an indiscriminate tool for obtaining sufficient knowledge, creating organizational agility (Ravichandran 2018). It also helps increase awareness in developing new products or services (Scuotto et al. 2017). These factors prescribe a dynamic capability within firms (Karimi-Alaghehband and Rivard 2019; Rezazadeh et al. 2016), even inseparable (Mikalef and Pateli 2017; McLaughlin 2017). These arguments serve as the foundation for the hypothesis formulation. 
Hypothesis 1. Hotels' existing technology supports the capacity of environmental support in innovation.

Hypothesis 2. The possession of superior technology enables the hotels to be more aware of potential innovative opportunities.

Hypothesis 3. Technology is the essential driver of hotels' dynamic capability.

The most important capital of hotels is their infrastructure, as it is the playground for their service. This physical manifestation is evident from the reviews of literature that mention its significant contribution as the perceived value (El-Adly 2019; Sürücü et al. 2019) or even brand image (Kandampully and Suhartanto 2000; Wai Lai 2019). Hotels with sustainably attributed infrastructures also shape customer loyalty (García de Leaniz and Rodríguez 2015). From the management perspective, the existing hotel infrastructures shape the service workers' capacity to create substantial innovation, especially in a crisis. However, the last pieces of literature discussing this nexus are still elusive. Han et al. (2021) examined the potential management infrastructure in hotels to adopt innovative mobile technology. Other studies mention innovative workplace design to boost creativity/smart working (Errichiello and Pianese 2020; van der Voordt 2003) and service climate (Al-Hawari et al. 2019; Ghosh 2015). The supporting infrastructure may play a role in cultivating innovative behavior (Singh and Sarkar 2019) from workers' happiness (Bani-Melhem et al. 2018). Ziyae et al. (2021) posit that the existing infrastructure is essential in creating dynamic capability in the hotel industry, manufacturing business (Anand et al. 2009), or real estate business (Stehn et al. 2021). These conversations add positive support for hypothesis formulation.

Hypothesis 4. Hotels' infrastructure is the supporting environment of innovation.

Hypothesis 5. Hotels' existing infrastructure is essential in securing the dynamic capability.

The organization's innovation norms-supporting environment to innovation and opportunity awareness-closely interact with the dynamic capability. These tenets refer to the environmental condition to support innovative behavior within firms (Russell and Russell 1992). This study proposes the relationship of supporting the environment within an organization toward opportunity awareness. This supportive condition may present from anything like managerial support, leadership, innovative environment, or funds. This nexus does not have too much attention from previous researchers. However, a study in data science indicated that data-driven culture leads to better opportunity sensing (de Medeiros et al. 2020). Non-location bound firm-specific advantages also increase the sensing process (Matysiak et al. 2018). Another study reveals that an immature environment requires other firms' openness to benefit the opportunities (Abidi and Koichi 2020). A supporting precondition of entrepreneurial and market orientation is crucial in the opportunity-seeking behavior (Bengesi and Roux 2014). This fact reiterates the importance of a dynamic environment to knowledge integration in finding potential innovation and even multiplied to firms focusing on radical innovation (Schnellbächer and Heidenreich 2020). Hotels' supporting environment toward creation leads to more dynamic capability (Seo et al. 2021; Coreynen et al. 2020). It presents as the inherent innovative environment critical in executing active strategies (Russell and Russell 1992). Finally, the opportunityseeking behavior would enhance the hotel's capacity in obtaining dynamic capabilities, as one foundational function of D.C. is the sensing quality (Kump et al. 2019; Baden-Fuller and Teece 2020; Zhou et al. 2019). Through these literature discussions, we present some hypotheses.

Hypotheses 6. Hotels' supporting environment, which encourages creativity, is essential in the workers' opportunity awareness. 
Hypothesis 7. By the presence of a supportive environment for innovation, the dynamic capability follows.

Hypothesis 8. Opportunity awareness also serves as the basis for dynamic hotels under turbulence.

Hypothesis 9. Supporting environment and opportunity awareness mediate the relationship of technological support and dynamic capability.

Hypothesis 10. Supporting environment and opportunity awareness mediate the relationship of infrastructure and dynamic capability.

\section{Materials and Methods}

\subsection{Design}

This study approaches the solutions to the proposed hypotheses by quantitative method. At best, this study is still exploratory by forming inferential statistics for the variable relationships. We develop a reflective model with five variables. Two independent predictors (technological support and infrastructure) construct direct and indirect relationships with three dependent variables (supporting environment, opportunity awareness, and dynamic capability). These interconnected variables are some strategic defensive stances that we believe to be critical during the adverse of COVID-19 (see Figure 1). An online questionnaire is selected to simplify the data collection using Google form with a 5point Likert scale. Provided this study was still in exploration, we employ a variance-based partial-least-square structural-equation-modeling for the analysis. This statistical method allows a more appropriate approach for this study's purposes with a loose assumption of normality in a theoretical development setting (Hair et al. 2017).

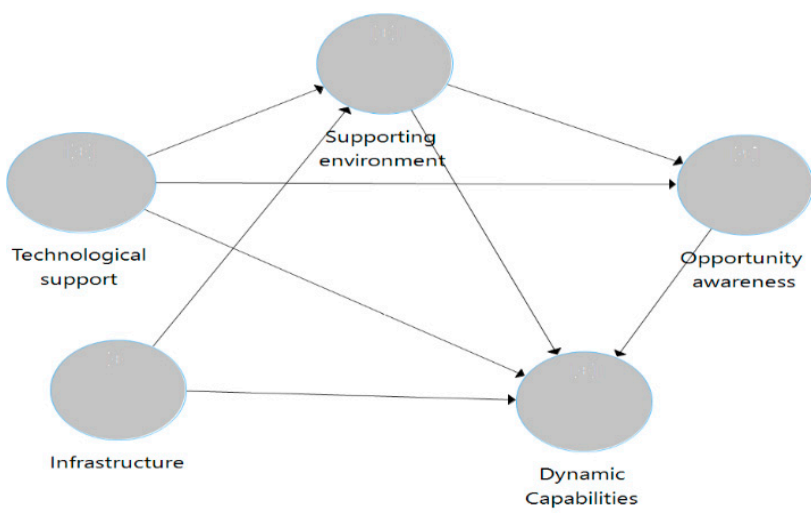

Figure 1. Conceptual framework (Source: authors' formulation).

This study's statistical measurements require several paths. Firstly, we need to clarify whether the indicators can represent the variables by the outer model quality. The deletion of the indicators has to consider the convergent validity tests like their Cronbach's alpha, rho_a, composite reliability, and average variant extractor. A deletion without an improvement in the model's validity is not advised. Furthermore, this study assured the model did not present a multicollinearity problem by its variant-inflation factors to be no higher than 3. Finally, we check the model discriminant validity by its heterotrait-monotrait test, with an expected value below 0.9. This test ensures that all indicators only represent the said variable instead of other unrelated constructs. These validity and reliability tests are the backbone for conducting the inner model measurement to observe the answers to the proposed hypotheses. All steps will be further explained in the result section.

\subsection{Sample}

The strategic formulation in a firm is usually an outcome of the thoughtful planning of the managers; thus, this study obtains the responses from a minimum of strategic-business- 
unit regulators. The hospitality business, especially the hotel industry, suffers the most from the adversities of COVID-19. Therefore, hotel management explores a myriad of defensive strategies to face these challenges. Another consideration for strategic data information is highly classified within firms; thus, we present a formal research letter from the university to the tourism department in Makassar. The agency then distributed it to the H.R.D. Managers. We also attach the letter in the questionnaire to convince them that our study only collects behavioral survey responses, and no credential data is required for the study. This gentle approach allows us to code 329 supervisory and above responses with a convenient sampling method. All managerial positions are considered equal in the responses with no further specifications in the statistical measurement. This sample size is sufficient from the perspective that the exact number of managerial populations is unknown. This dataset is larger than the ten times indicator rule for PLS-SEM, as this study has 18 scales in the investigation (Hair et al. 2016, 2010) and higher than the 200 cut-off points for structural-equation modeling (Boomsma 1985; Kline 1998). Table 1 compiles the demographic background of these decision-makers. No data went missing, as this study used Google Forms to ensure precision. This study obtained 329 usable responses from upper-level management. They vary in their positions, with several demographic characteristics as follows:

Table 1. Demographic characteristics.

\begin{tabular}{lcclcc}
\hline \multicolumn{1}{c}{ Descriptions } & $\mathbf{n}$ & $\mathbf{\%}$ & \multicolumn{1}{c}{ Descriptions } & $\mathbf{n}$ & $\mathbf{\%}$ \\
\hline Sex & & & Positions & & \\
Male & 197 & 59.88 & GM & 33 & 10.03 \\
Female & 132 & 40.12 & Accounting Manager & 27 & 8.20 \\
Total & 329 & 100 & HRD Manager & 72 & 21.88 \\
Age & & & Marketing Supervisor & 52 & 15.80 \\
18-30 & 39 & 11.85 & F\&B Manager & 67 & 20.36 \\
31-45 & 203 & 61.70 & Room Manager & 23 & 6.99 \\
46-60 & 87 & 26.44 & Supervisor & 55 & 16.71 \\
Education & & & Tenure & & \\
High school & 32 & 15.6 & 1-3 years & 46 & 13.98 \\
D1 & 42 & 4.9 & 4-6 years & 117 & 35.56 \\
D3 & 63 & 20.5 & 7-10 years & 97 & 29.48 \\
Bachelor & 192 & 58.8 & $>10$ years & 69 & 20.97 \\
\hline Source Respondents ${ }^{\prime}$ profile in the & & & & \\
\hline
\end{tabular}

Source: Respondents' profile in the survey.

The respondents' responses reveal some demographic information, with the sample being dominated by men, 197 people, representing $59.88 \%$ of the data. They are also generally productive age, i.e., 31-45 years, possessing a bachelor's degree. HRD Managers would screen the research permit and the questionnaires first; thus, they present as the highest respondents, followed by the food and beverage managers and supervisors in various positions. Respondents have generally served for 4-7 years.

\subsection{Measures}

This study investigates five variables of interest and obtains the indicators from several previous research articles. All exogenous variables (technological support and infrastructure) are what we believe as accumulated past competitive resources pertaining to support the formation of innovative norms and dynamic capabilities of a firm (Suddaby et al. 2010). As the hotels would not be able to add current investment and use what is available, this past possession serves as an added value compared to competitors. Technological supports follow the indicator formulation with three items. This construct explains how management has compiled a range of technological resources to support the service offerings. While information system capacity is critical, previous competitiveness also presents how different the hotels' physical offerings are. Thus, this study places the hotel's infrastructure as essential to provide guests with a primary and standardized ambiance. It is accumulated 
in the vibrant atmosphere of the infrastructure. It follows how hotels manage to fortify the continuity of service offerings' quality and serve the hotel's identity (Choi and Chu 2001). These two constructs will provide the landmark for the innovation capacity in maintaining the dynamic capabilities within firms.

This study proposes two innovation norms within the organization as the mediating variables to sustain dynamic capabilities, i.e., supporting the environment and opportunity awareness. The construct measurements follow categorization as how proposed innovation norms, i.e., knowledge awareness, attitude toward innovation, the process of innovation, and its implementation within the organization, are critical for a dynamic workplace (Russell and Russell 1992). As such, they are some of the substantial foundations for the establishment of dynamic capability. The construct measurements are adapted from $\mathrm{Wu}$ (2007), which compile the capability to integrate resources, the capacity to reconfigure resources, the ability to learn, and the ability to respond to rapid changes in the business environment. As this study employs the measurement from previous publications which have passed the data quality requirements, the initial ground for the study presentation can be laid out for the context of market turbulence under COVID-19.

\section{Results}

Descriptive information from the response data is shown in Table 2.

Table 2. Mean, standardized deviations, and correlations of constructs.

\begin{tabular}{|c|c|c|c|c|c|c|c|c|}
\hline No & Constructs & Mean & SD & 1 & 2 & 3 & 4 & 5 \\
\hline 1 & Opportunity awareness & 4.289 & 0.939 & 1.000 & & & & \\
\hline 2 & Supporting environment & 4.164 & 1.045 & 0.550 & 1.000 & & & \\
\hline 3 & Technological support & 3.872 & 1.164 & 0.307 & 0.350 & 1.000 & & \\
\hline 4 & Infrastructure & 4.212 & 0.782 & 0.367 & 0.497 & 0.496 & 1.000 & \\
\hline 5 & Dynamic capabilities & 4.041 & 0.958 & 0.356 & 0.481 & 0.536 & 0.607 & 1.000 \\
\hline
\end{tabular}

Data analysis using PLS-SEM divided the analysis stages into two parts: the outer and inner models. The outer model provides information about the validity and reliability of the data proposed in the study. Thirty-one initial scales were reduced into 18 final indicators by the composite confirmatory analysis (C.C.A.) stage, which has become the identity of PLS-SEM (Schuberth et al. 2018). These items must meet several criteria: the loading factor's quality, convergent validity, discriminant validity, and collinearity. Table 3 summarizes outer model findings.

The C.C.A. study confirmed the support for the outer structure of this research model. This fact comes from a variety of information. The final 18 indicators have a loading value that is not lower than 0.6. Hair et al. (2014b) provide a standard that, ideally, the loading value should be higher than 0.7 ; however, this level is not mandatory. They do not suggest removing the indicator if it does not improve the alpha or average variance extractor (AVE). The nature of this research, which tends to explore the theory, also supports a low loading value, as long as it is not less than 0.5 . Therefore, these 18 indicators can be proposed to the subsequent validity and reliability test.

The convergent validity test in this study observes the Cronbach's alpha, rho-a, composite reliability, and the AVE of the data. Except for AVE ( $>0.5$ is expected), all of these measures are required to have a value above 0.7 . Table 3 provides information that the opportunity awareness and dynamic capability variables do not meet the 0.7 level. It can be explained that some alternative criteria such as composite reliability and AVE provide support for models with values above 0.7 and 0.5 in the overall construct. Moreover, exploratory-based research also does not need a high alpha value (Taber 2018). On the other hand, the AVE itself is seen as one of the more stringent measures of validity quality than Cronbach's alpha (Hair et al. 2014a). Thus the convergent validity test is sufficient, and the investigation of multicollinearity can be performed. 
Table 3. Measurement specifications of outer model.

\begin{tabular}{|c|c|c|c|c|c|c|c|}
\hline Construct & Indicators & Loading & Alpha & rho_A & CR & AVE & VIF \\
\hline \multirow{3}{*}{ Dynamic Capabilities } & DynCap1 & 0.823 & \multirow{3}{*}{0.639} & \multirow{3}{*}{0.637} & \multirow{3}{*}{0.806} & \multirow{3}{*}{0.582} & 1.628 \\
\hline & DynCap2 & 0.768 & & & & & 1.598 \\
\hline & DynCap3 & 0.691 & & & & & 1.089 \\
\hline \multirow{4}{*}{ Infrastructure } & Infr1 & 0.638 & \multirow{4}{*}{0.706} & \multirow{4}{*}{0.748} & \multirow{4}{*}{0.819} & \multirow{4}{*}{0.534} & 1.401 \\
\hline & Infr2 & 0.855 & & & & & 1.790 \\
\hline & Infr3 & 0.768 & & & & & 1.565 \\
\hline & Infr4 & 0.640 & & & & & 1.328 \\
\hline \multirow{3}{*}{ Opportunity awareness } & OppA1 & 0.618 & \multirow{3}{*}{0.579} & \multirow{3}{*}{0.601} & \multirow{3}{*}{0.774} & \multirow{3}{*}{0.537} & 1.237 \\
\hline & OppA2 & 0.805 & & & & & 1.350 \\
\hline & OppA3 & 0.762 & & & & & 1.126 \\
\hline \multirow{5}{*}{ Supporting environment } & SupEnv1 & 0.845 & \multirow{5}{*}{0.897} & \multirow{5}{*}{0.898} & \multirow{5}{*}{0.924} & \multirow{5}{*}{0.708} & 2.743 \\
\hline & SupEnv2 & 0.858 & & & & & 2.822 \\
\hline & SupEnv3 & 0.821 & & & & & 2.213 \\
\hline & SupEnv4 & 0.865 & & & & & 2.665 \\
\hline & SupEnv5 & 0.819 & & & & & 2.108 \\
\hline \multirow{3}{*}{ Technological support } & TechCS1 & 0.947 & \multirow{3}{*}{0.803} & \multirow{3}{*}{0.927} & \multirow{3}{*}{0.881} & \multirow{3}{*}{0.720} & 3.715 \\
\hline & TechCS2 & 0.949 & & & & & 3.722 \\
\hline & TechCS3 & 0.602 & & & & & 1.261 \\
\hline
\end{tabular}

Source: Adapted Smartpls3 output.

Table 3 provides information on the potential for collinearity in the data. The test results indicate the absence of this problem with a variance inflation factor (V.I.F.) value above 0.2 and below ten on all final data indicators. V.I.F. also provides information about the standard method bias (Podsakoff et al. 2003). The TechCS1 and TechCS2 hands have a V.I.F. above 3, but it is still considered moderate because it is still below the five thresholds (Kock 2015). Based on the information in Table 3 above, the research data has met the PLS-SEM outer criteria, leaving the discriminant validity test as in Table 4.

Table 4. The heterotrait-monotrait (HTMT).

\begin{tabular}{ccccccc}
\hline \multicolumn{1}{c}{ HTMT } & $\mathbf{1}$ & $\mathbf{2}$ & $\mathbf{3}$ & $\mathbf{4}$ & $\mathbf{5}$ \\
\hline 1 & Dynamic Capabilities & & & & & \\
2 & Infrastructure & 0.862 & & & & \\
3 & Opportunity awareness & 0.422 & 0.508 & & & \\
4 & Supporting environment & 0.620 & 0.626 & 0.719 & & \\
5 & Technological support & 0.717 & 0.639 & 0.439 & 0.409 & \\
\hline
\end{tabular}

Source: Smartpls 3 output.

This study seeks to ensure that all indicators in the survey can represent their variables within the framework of discriminant validity analysis. Table 4 provides information on the research using the heterotrait-monotrait test (HTMT), which supports the proposed model and indicators. All variables have values below 0.9 based on the recommendations of PLS-SEM use (Henseler et al. 2015). As all validity and reliability pre-tests meet the requirements, the analysis shifts to the path coefficients and the bootstrapping results. The statistical tests reveal the findings as in Table 5. 
Table 5. The Summary of significance and relevance tests.

\begin{tabular}{lccc}
\multicolumn{1}{c}{ Relationships } & Effect & $\boldsymbol{t}$-Value & $p$-Value \\
\hline Technological support -> Supporting environment & 0.165 & 2.271 & 0.023 \\
Technological support -> Opportunity awareness & 0.113 & 2.007 & 0.045 \\
Technological support -> Dynamic capabilities & 0.290 & 5.129 & 0.000 \\
Infrastructure -> Supporting environment & 0.424 & 6.448 & 0.000 \\
Infrastructure -> Dynamic capabilities & 0.369 & 6.458 & 0.000 \\
Supporting environment -> Opportunity awareness & 0.494 & 7.881 & 0.000 \\
Supporting environment -> Dynamic capabilities & 0.201 & 3.100 & 0.002 \\
Opportunity awareness -> Dynamic capabilities & -0.035 & 0.500 & 0.617 \\
Tech. support -> Supp. envrmnt -> Opp. awrn -> Dyn. capabilities & 0.003 & 0.433 & 0.665 \\
Infrastructure -> Supp. envrmnt. -> Opp. awrn -> Dyn. capabilities & 0.007 & 0.494 & 0.622 \\
$\mathrm{R}^{2}$ to Supporting environment & & 0.277 \\
$\mathrm{R}^{2}$ to Opportunity awareness & & 0.299 \\
$\mathrm{R}^{2}$ to Dynamic capabilities & & 0.467 \\
\hline
\end{tabular}

Source: Adapted Smartpls3 output.

Table 5 reveals the acceptance of nearly all hypotheses directly, but the relationship of opportunity awareness and dynamic capability. This study also provides the empirical path model as observed in Figure 2.

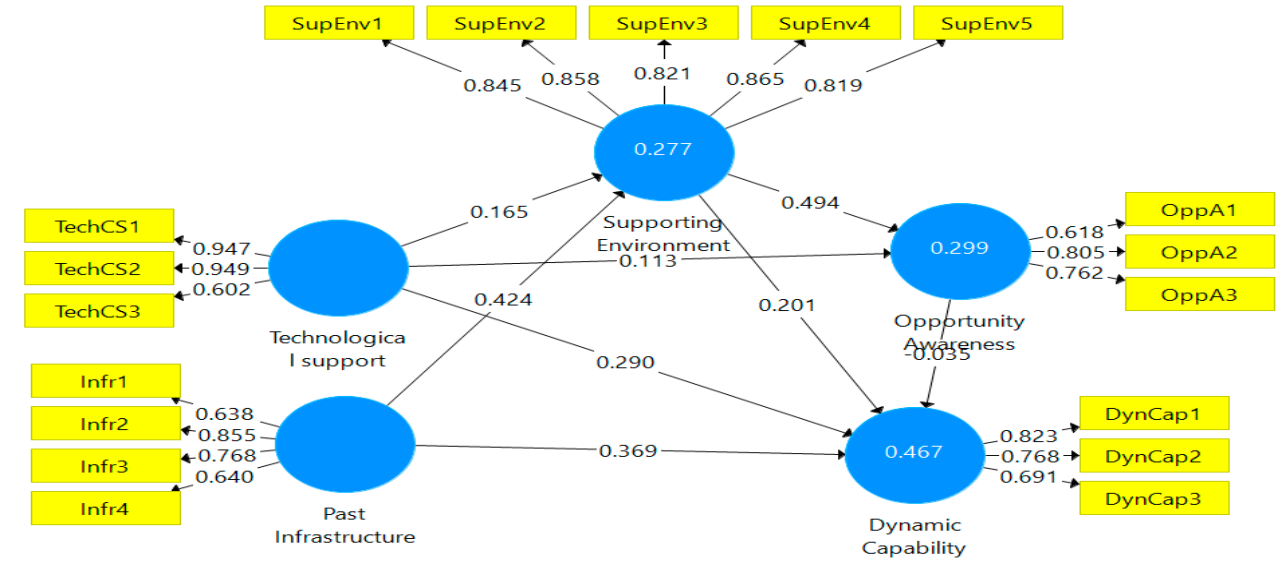

Figure 2. The path model (Source: Smartpls3 output).

All significant relationships satisfy the 1.96 minimum requirement for a $5 \%$ margin of error. The $R^{2}$ of the three endogenous variables varies with the dynamic capability to obtain the highest value. This revelation is understandable as all paths finally end in this variable; thus, the number of relationships is advised (see Figure 2, the statistical path revelation). The statistical tests support the central idea formulation of past resource advantages in pushing the innovative norms and dynamic capabilities in a turbulent time and will be discussed further.

\section{Discussion}

The dynamics of competition in the hospitality business face enormous challenges from significant environmental changes such as COVID-19. Loss of revenue in the hotel sector and job losses are saddening phenomena (Razak 2020). Therefore, maximizing existing resources is one of the steps commonly taken by managers to mitigate the problems (De Belvis et al. 2012). This study examines the interaction between resource ownership, innovation norms, and the dynamic capability of the hospitality industry to defend itself in times of crisis. Two critical resources inherent and unchanged in the hotel business are ownership of the information technology structure and hotel infrastructure. These two investments are generally owned before COVID-19 strikes, so adopting the right technology (Tavitiyaman et al. 2020) and the quality of infrastructure is a strategic position in turbulent times (Assaf et al. 2015). 
This study confirms the formulation of Hypothesis 1 that technology support is critical in developing an innovative environment that supports the adaptability of its employees. The organization must conduct various interventions to form a strategic environment that can help team members creatively deal with market demand (Mumford 2000). Technological support is essential in shaping a creative work environment (Zhou and Verburg 2020; Aydalot and Keeble 2018). A study on 340 companies in China supports that the readiness of technological resources is an essential factor in creating and safeguarding a competitive work environment for organizational performance (Zhang et al. 2020). As a supporter of an innovative environment, technology will play a crucial role in the knowledge generation process, forming a competitive advantage in service firms (Macau et al. 2016). However, knowledge is not always essential or strategic. When possession of knowledge cannot drive competitive advantage, Grover et al. (2009) propose finding and strengthening other distinctive factors within the organization.

Technological support as a strategic resource is also an element of forming innovative norms in the form of a work environment that is aware of various opportunities and strategic strengths to overcome threats and weaknesses for the organization. The results of the Hypothesis 2 test significantly confirm the above conceptualization that technological support is crucial for establishing opportunity awareness. The relationship between these variables has not been studied in depth from previous studies. However, lessons from previous research indicate that being aware of change is essential when in an environment experiencing disruptive changes in technology (Birkinshaw et al. 2018). Their research confirms that the most prominent investment will be in late-mover companies, leading to the loss of competitiveness in the process. Other studies indicate the importance of a decision support system for technology to assist in a better environmental scanning process (Villalobos et al. 2019). Further studies in education support technology's role in shaping adaptive personalities in learning (Järvenoja et al. 2020), thus providing cues for future research.

Dependable technology ownership is one of the backbones in creating a dynamic organization. This argument is evident from the confirmation of Hypothesis 3, namely, the role of technical support in improving dynamic hotel capabilities. Previous research has indicated the role of big data-based technology capacity in Norway in shaping active organizations and leading to organizational competitive advantage (Mikalef et al. 2020). The shift towards mobile technology has also created a new offering in the hotel business (Han et al. 2021). The experience of the company's past exponential development in South Korea stems from the adoption of qualified technology for proponent innovation in the world (Kim and Lee 2002). Technological support in the industry is the basis for the value creation of a dynamic company (Chen et al. 2015). However, the hotel's technical capacity is meaningless without the possession of adequate infrastructure resources.

Hotel infrastructure is a fixed asset serving as the leading offers to customers ( $\mathrm{Chu}$ and Choi 2000; Choi and Chu 2001). These resources accumulate past investments that confirm the hotel's position and become the starting point for the hotel's performance. The flexibility of maximizing the use of hotel infrastructure in shaping a supportive work environment to innovation is one of the relationships in this study with the most significant effect $(42 \%)$, confirming Hypothesis 4 . Notably, the relationship between these variables has not been studied in depth from previous studies. A proxy study found that adequate infrastructure capability is essential in shaping an innovative environment (Chuang et al. 2016). Continuous infrastructure improvement is the basis for hotel innovation in producing more attractive customer offers (Bondarenko et al. 2019). These results provide a strong argument that hotels with more established ownership of infrastructure resources will make it easier for employees to design more attractive service offerings to customers. The results of a cross-country study also find that internal infrastructure capacity is more critical in innovative processes for companies in developing countries than in developed countries (Dwivedi et al. 2015). The potential for developing hotel infrastructure in the future could consider the development of extra-sensory experiences, hyper-personalized 
experiences, and beyond-automation experiences (Buhalis et al. 2019). The continuous process of updating infrastructure will strengthen the dynamics of hotel offerings (Sadeghi), especially in times of crisis.

Hotels with infrastructure that enable dynamic strategic offerings for customers can grow much better, as evident from the findings of this study that hotel infrastructure is a driving element of dynamic capability hotels, confirming Hypothesis 5. This finding is supported by qualitative research from previous researchers (Ziyae et al. 2021). Good infrastructure also facilitates business flexibility responsive to various opportunities in the acquisition and merger process, even during integration between companies (Benitez et al. 2018). On the other hand, a commitment to good infrastructure ownership will be essential in becoming a dynamic organization that can sense and respond to various potential offers in the market (Roberts and Grover 2012). Commitment to energy-friendly infrastructure may also play a role in a more dynamic hotel (Crapolicchio et al. 2020). In times of crisis, when all efforts must be maximized, the ownership of strategic resources that are easy to configure will be an essential element in maintaining a dynamic hotel business.

An innovative internal structure serves as a strategic resource that can sustainably support the hospitality business's performance in a turbulent market (Cheah et al. 2018). The reason is that innovation norms are the basis for preparing the adaptive business model in a crisis. The hotel business environment that facilitates and supports the innovation process of its employees will increase their sensing and capture potential opportunities, confirming Hypothesis 6. The relationship between these variables reveals the most extensive influence $(49 \%)$ in this study, emphasizing its essential role. These findings highlight the vital role of innovation norms in the adaptive creativity of employees (Russell and Russell 1992). Being aware of various changes is a necessary key in initiating strategic actions on time, and therefore requires good internal capabilities in responding to these changes (Al-Kwifi et al. 2020). The ownership of open culture to innovation encourages creating an adaptive organization in sensing and seizing potential opportunities (Duarte Alonso et al. 2020; Matysiak et al. 2018). This study confirms Hypothesis 7 that an environment that supports the innovation process is crucial in a dynamic organization. Management openness to embracing a wide range of innovation activities will increase successful innovation in improving organizational financial performance (Piening and Salge 2015).

On the other hand, the awareness of potential opportunities does not automatically lead to dynamic capability, leading to the rejection of Hypothesis 8 . The study indicates that taking action is crucial as the information may overwhelm the decision-makers, making them not dynamic (Purnomo 2018). Opportunity identification is not enough without appropriate adaptation (Marhraoui and Manouar 2017). Adequate investment in the opportunity sensing process is crucial (Giudici et al. 2016). This insignificant relationship can also get a more in-depth explanation in future research by accommodating these various factors.

Statistically, the insignificant relationship between opportunity awareness to dynamic capability makes all indirect connections through these two constructs trivial, rejecting Hypotheses 9 and 10. Exceptions can be made if the opportunity variable becomes the last dependent construct in indirect relationships or does not become a mediating variable. Measurement improvement or review may clarify the findings of this study. All results confirm that resource ownership is vital in shaping the innovative environment in the organization and leads to a dynamic organization. However, business competition does not always have to be at constant fights. Cooperation between competing businesses within the impacted industry seems to be an inevitable strategy to survive the challenges (Crick and Crick 2020).

One highly prized solution for this pandemic is the vaccination program. The faster the jabs, the earlier the dream to new-normal life arrives, and thus, requires immediate pressure from the community to do the job (Smith 2021). Even when there is a vaccine shortage, a targeted vaccination in Indonesia seems to do the job just right (Fuady et al. 2021). This strategy faces news misinterpretation, hoaxes, fallacy, and other misinformation 
(Dzinamarira et al. 2021; Sallam et al. 2021; French et al. 2020), and thus requires extensive communication strategy from all levels of communities (Adebisi et al. 2021; Alwi et al. 2021; Kurniansyah et al. 2021). Several efforts are administered to speed up the vaccination program in the context of tourism. Vaccine tourism is the new approach taken by countries like the USA to restart the ill sector and has gained some popularity (Gulati 2021; HigginsDesbiolles et al. 2021). Whatever the cases, an intensive vaccination program is undoubtedly the aspired holy grail to curb the severely impaired tourism sector (Williams et al. 2021).

The confusion of COVID-19 to early risk management in the tourism sector is evident (Radic et al. 2020), thus requiring new approaches (Škare et al. 2021). Along with the speed of the vaccination program (Smith 2021; Fuady et al. 2021), aggressive marketing efforts have to be established to secure the business position (Lee et al. 2021). This study proposes that an internally innovative environment may ensure the competitive edge in the transition to new-normal (Caballero-Morales 2021). The new risk management must accommodate integrating a public health strategy and risk management system (Kim 2020). Management must ensure workplace health to support the workforce's confidence to return to the office (Dennerlein et al. 2020). Whatever the solutions, this global health turbulence necessitates a new approach in designing a novel risk-management system. This COVID-19 pandemic has displayed the many efforts of business organizations to sustain life, as so do we, humans.

\section{Conclusions}

This study indicated that the hotel industry needs to regulate itself within an adaptive organization framework. Possessing past strategic resources, i.e., technological support and infrastructure, becomes an inevitable strength when new investment is dire. They are foundational to creating innovative norms, i.e., supporting the environment and opportunity awareness within the organization. Finally, all constructs are the backbone of the hotels' dynamic capability. While the strategic resources may present from every corner of the company, the formulation of this study that limits the two variables may improve with the addition of some predictors-specific skills, cooperation, or even the hotel chain. Innovation norms also require concrete action and knowledge in the process, further indicating the presence of potential intermediaries. We leave this to other aspiring authors.

This study came with certain limitations. Firstly, the data set was only in one developing region, so generalization must be addressed carefully. Future studies could gain further insight by increasing the area under observation. Secondly, this study encountered issues of collecting more extensive data, as the number of managers is limited. Future studies could gain more information by comparing developing and developed regions, as this study is still exploratory. Thirdly, this study assumed all managerial responses to be equal, while the hotels differed in size, assets, local/international chain hotels, and the star level. These weaknesses may decrease the explanatory power of the research. We leave this to future studies.

Author Contributions: Conceptualization, M.Y.A. and A.S.; methodology, A.S.; software, A.S.; validation, R.D.A.P. and R.R.; formal analysis, A.S.; investigation, M.Y.A.; resources, M.Y.A.; data curation, R.R.; writing—original draft preparation, M.Y.A.; writing—review and editing, M.Y.A.; visualization, A.S.; supervision, M.Y.A.; project administration, R.R. and R.D.A.P. All authors have read and agreed to the published version of the manuscript.

Funding: This research received no external funding.

Institutional Review Board Statement: Not applicable.

Informed Consent Statement: Not applicable.

Data Availability Statement: The study did not report any data.

Conflicts of Interest: The authors declare no conflict of interest. 


\section{References}

Abidi, Dora, and Nakagawa Koichi. 2020. Management Approach for Innovation Success in Unstable and Stable Environments: Opportunity-Based Approach vs. Administrative Control Approach. Competitiveness Review 30: 22-40. [CrossRef]

Adebisi, Yusuff Adebayo, Adrian Rabe, and Don Eliseo Lucero-Prisno. 2021. Risk Communication and Community Engagement Strategies for COVID-19 in 13 African Countries. Health Promotion Perspectives 11: 137-47. [CrossRef]

Al-Hawari, Mohd A., Shaker Bani-Melhem, and Faridahwati Mohd Shamsudin. 2019. Determinants of Frontline Employee Service Innovative Behavior: The Moderating Role of Co-Worker Socializing and Service Climate. Management Research Review 42 1076-94. [CrossRef]

Al-Kwifi, Osama Sam, Allam K.Abu Farha, and Wael S. Zaraket. 2020. Competitive Dynamics Between Multinational Companies and Local Rivals in Emerging Markets. FIIB Business Review 9: 189-204. [CrossRef]

Alwi, Zulfahmi, Rika Dwi Ayu Parmitasari, and Alim Syariati. 2021. “An Assessment on Islamic Banking Ethics through Some Salient Points in the Prophetic Tradition". Heliyon 7: e07103. [CrossRef] [PubMed]

Amui, Lara Bartocci Liboni, Charbel Jose Chiappetta Jabbour, Ana Beatriz Lopes de Sousa Jabbour, and Devika Kannan. 2017. Sustainability as a Dynamic Organizational Capability: A Systematic Review and a Future Agenda toward a Sustainable Transition. Journal of Cleaner Production 142: 308-22. [CrossRef]

Anand, Gopesh, Peter T. Ward, Mohan V. Tatikonda, and David A. Schilling. 2009. Dynamic Capabilities through Continuous Improvement Infrastructure. Journal of Operations Management 27: 444-61. [CrossRef]

Arend, Richard J., and Philip Bromiley. 2009. Assessing the Dynamic Capabilities View: Spare Change, Everyone? Strategic Organization 7. [CrossRef]

Assaf, A. George, Alexander Josiassen, and Frank W. Agbola. 2015. Attracting International Hotels: Locational Factors That Matter Most. Tourism Management 47: 329-40. [CrossRef]

Aydalot, Philippe, and David Keeble. 2018. High Technology Industry and Innovative Environments: The European Experience. High Technology Industry and Innovative Environments: The European Experience. London: Routledge. [CrossRef]

Baden-Fuller, Charles, and David J. Teece. 2020. Market Sensing, Dynamic Capability, and Competitive Dynamics. Industrial Marketing Management 89: 105-6. [CrossRef]

Bani-Melhem, Shaker, Rachid Zeffane, and Mohamed Albaity. 2018. Determinants of Employees' Innovative Behavior. International Journal of Contemporary Hospitality Management 30: 1601-20. [CrossRef]

Barney, Jay. 1991. Firm Resources and Sustained Competitive Advantage. Journal of Management 17: 99-120. [CrossRef]

Barney, Jay B. 2001. Is the Resource-Based 'View' a Useful Perspective for Strategic Management Research? Yes. Academy of Management Review 26: 22-40. [CrossRef]

De Belvis, Antonio Giulio, Francesca Ferrè, Maria Lucia Specchia, Luca Valerio, Giovanni Fattore, and Walter Ricciardi. 2012. The Financial Crisis in Italy: Implications for the Healthcare Sector. Health Policy 106: 10-16. [CrossRef]

Bengesi, Kenneth M. K., and Ingrid Le Roux. 2014. Strategic Entrepreneurial Response of Small and Medium Enterprises in Developing Economies. International Journal of Business and Management 9: 153-65. [CrossRef]

Benitez, Jose, Gautam Ray, and Jörg Henseler. 2018. Impact of Information Technology Infrastructure Flexibility on Mergers and Acquisitions. MIS Quarterly: Management Information Systems 42: 25-44. [CrossRef]

Birkinshaw, Julian, Ivanka Visnjic, and Simon Best. 2018. Responding to a Potentially Disruptive Technology: How Big Pharma Embraced Biotechnology. California Management Review 60: 74-100. [CrossRef]

Bondarenko, Viktoria Andreevna, I. N. Efremenko, and Vladimir Alexandrovich Larionov. 2019. Marketing Strategy for Hotel and Tourist Complex Companies. International Journal of Economics and Business Administration 7: 388-94.

Boomsma, Anne. 1985. Nonconvergence, Improper Solutions, and Starting Values in Lisrel Maximum Likelihood Estimation. Psychometrika 50: 229-42. [CrossRef]

Buhalis, Dimitrios, Tracy Harwood, Vanja Bogicevic, Giampaolo Viglia, Srikanth Beldona, and Charles Hofacker. 2019. Technological Disruptions in Services: Lessons from Tourism and Hospitality. Journal of Service Management 30: 484-506. [CrossRef]

Caballero-Morales, Santiago Omar. 2021. Innovation as Recovery Strategy for SMEs in Emerging Economies during the COVID-19 Pandemic. Research in International Business and Finance 57: 101396. [CrossRef]

Cappelli, Peter, and Anne Crocker-Hefter. 1996. Distinctive Human Resources Are Firms' Core Competencies. Organizational Dynamics 24: 7-22. [CrossRef]

Chancharoenthana, Wiwat, Asada Leelahavanichkul, Sutatip Chinpraditsuk, Krit Pongpirul, Supitcha Kamolratanakul, Weerapong Phumratanaprapin, Polrat Wilairatana, and Punnee Pitisuttithum. 2021. Social Restriction versus Herd Immunity Policies in the Early Phase of the SARS-CoV-2 Pandemic: A Mathematical Modelling Study. Asian Pacific Journal of Allergy and Immunology. [CrossRef]

Chatterjee, Sheshadri, Ranjan Chaudhuri, and Demetris Vrontis. 2021. Does Data-Driven Culture Impact Innovation and Performance of a Firm? An Empirical Examination. Annals of Operations Research, 1-26. [CrossRef]

Cheah, Sarah, Yuen Ping Ho, and Shiyu Li. 2018. Business Model Innovation for Sustainable Performance in Retail and Hospitality Industries. Sustainability 10: 3952. [CrossRef]

Chen, Daniel Q., David S. Preston, and Morgan Swink. 2015. How the Use of Big Data Analytics Affects Value Creation in Supply Chain Management. Journal of Management Information Systems 32: 4-39. [CrossRef] 
Choi, Tat Y., and Raymond Chu. 2001. Determinants of Hotel Guests' Satisfaction and Repeat Patronage in the Hong Kong Hotel Industry. International Journal of Hospitality Management 20: 277-97. [CrossRef]

Chu, Raymond K. S., and Tat Choi. 2000. An Importance-Performance Analysis of Hotel Selection Factors in the Hong Kong Hotel Industry: A Comparison of Business and Leisure Travellers. Tourism Management 21: 363-77. [CrossRef]

Chuang, Shu Hui, Shinyi Lin, and Tin Chang Chang. 2016. Exploring the Performance of Service Innovation: Infrastructure Capability and Innovation Orientation Complementarity. Paper presented at 2016 10th International Conference on Innovative Mobile and Internet Services in Ubiquitous Computing, IMIS 2016, Fukuoka, Japan, July 6-8.

Coccia, Mario. 2022. Preparedness of Countries to Face COVID-19 Pandemic Crisis: Strategic Positioning and Factors Supporting Effective Strategies of Prevention of Pandemic Threats. Environmental Research 203: 111678. [CrossRef]

Coreynen, Wim, Paul Matthyssens, Johanna Vanderstraeten, and Arjen van Witteloostuijn. 2020. Unravelling the Internal and External Drivers of Digital Servitization: A Dynamic Capabilities and Contingency Perspective on Firm Strategy. Industrial Marketing Management 89: 265-77. [CrossRef]

Crapolicchio, Martina, Henrique de Carvalho, Karim Chaitani, and Simone Longobardi. 2020. Sustainability in the Italian Hotel Infrastructure: Is It a Priority for Decision-Makers? CERN IdeaSquare Journal of Experimental Innovation 4: 30-36. [CrossRef]

Crick, James M., and Dave Crick. 2020. Coopetition and COVID-19: Collaborative Business-to-Business Marketing Strategies in a Pandemic Crisis. Industrial Marketing Management 88: 206-13. [CrossRef]

de Medeiros, Mauricius Munhoz, Norberto Hoppen, and Antonio Carlos Gastaud Maçada. 2020. Data Science for Business: Benefits, Challenges and Opportunities. Bottom Line 33: 149-63. [CrossRef]

de Vlas, Sake J., and Luc E. Coffeng. 2021. Achieving Herd Immunity against COVID-19 at the Country Level by the Exit Strategy of a Phased Lift of Control. Scientific Reports 11: 1-7. [CrossRef]

Dennerlein, Jack T., Lisa Burke, Erika L. Sabbath, Jessica A.R. Williams, Susan E. Peters, Lorraine Wallace, Melissa Karapanos, and Glorian Sorensen. 2020. An Integrative Total Worker Health Framework for Keeping Workers Safe and Healthy During the COVID-19 Pandemic. Human Factors 62: 689-96. [CrossRef] [PubMed]

Díaz, Mónica Méndez, and Clara Martín Duque. 2021. Open Innovation through Customer Satisfaction: A Logit Model to Explain Customer Recommendations in the Hotel Sector. Journal of Open Innovation: Technology, Market, and Complexity 7: 180. [CrossRef]

Dobrowolski, Zbyslaw. 2021. Why Some Countries Win and Others Loose from the COVID-19 Pandemic? Navigating the Uncertainty. European Research Studies Journal 24: 1217-26. [CrossRef]

Drozdowski, Grzegorz, Joanna Rogozińska-Mitrut, and Jacek Stasiak. 2021. The Empirical Analysis of the Core Competencies of the Company's Resource Management Risk. Preliminary Study. Risks 9: 107. [CrossRef]

Duarte Alonso, Abel, Seng Kiat Kok, Alessandro Bressan, Michelle O'Shea, Nikolaos Sakellarios, Alex Koresis, Maria Alejandra Buitrago Solis, and Leonardo J. Santoni. 2020. COVID-19, Aftermath, Impacts, and Hospitality Firms: An International Perspective. International Journal of Hospitality Management 91: 102654. [CrossRef] [PubMed]

Dwivedi, Abhishek, Lester W. Johnson, and Robert E. McDonald. 2015. Celebrity Endorsement, Self-Brand Connection and ConsumerBased Brand Equity. Journal of Product and Brand Management 24: 449-61. [CrossRef]

Dzinamarira, Tafadzwa, Brian Nachipo, Bright Phiri, and Godfrey Musuka. 2021. Covid-19 Vaccine Roll-out in South Africa and Zimbabwe: Urgent Need to Address Community Preparedness, Fears and Hesitancy. Vaccines 9: 250. [CrossRef] [PubMed]

Eden, Colin, and Fran Ackermann. 2000. Mapping Distinctive Competencies: A Systemic Approach. Journal of the Operational Research Society 51: 12-20. [CrossRef]

Eisenhardt, Kathleen M., and Jeffrey A. Martin. 2000. Dynamic Capabilities: What Are They? Strategic Management Journal 21: 1105-21. [CrossRef]

El-Adly, Mohammed Ismail. 2019. Modelling the Relationship between Hotel Perceived Value, Customer Satisfaction, and Customer Loyalty. Journal of Retailing and Consumer Services 50: 322-32. [CrossRef]

Errichiello, Luisa, and Tommasina Pianese. 2020. Toward a Theory on Workplaces for Smart Workers. Facilities 38: 298-315. [CrossRef]

French, Jeff, Sameer Deshpande, William Evans, and Rafael Obregon. 2020. Key Guidelines in Developing a Pre-Emptive COVID-19 Vaccination Uptake Promotion Strategy. International Journal of Environmental Research and Public Health 17: 5893. [CrossRef] [PubMed]

Fuady, Ahmad, Nuning Nuraini, Kamal K. Sukandar, and Bony W. Lestari. 2021. Targeted Vaccine Allocation Could Increase the Covid-19 Vaccine Benefits amidst Its Lack of Availability: A Mathematical Modeling Study in Indonesia. Vaccines 9: 462. [CrossRef] [PubMed]

Fukawa, Nobuyuki, Yanzhi Zhang, and Sunil Erevelles. 2021. Dynamic Capability and Open-Source Strategy in the Age of Digital Transformation. Journal of Open Innovation: Technology, Market, and Complexity 7: 175. [CrossRef]

García de Leaniz, Patricia Martínez, and Ignacio Rodríguez Del Bosque Rodríguez. 2015. Exploring the Antecedents of Hotel Customer Loyalty: A Social Identity Perspective. Journal of Hospitality Marketing and Management 24: 1-23. [CrossRef]

Ghosh, Koustab. 2015. Developing Organizational Creativity and Innovation: Toward a Model of Self-Leadership, Employee Creativity, Creativity Climate and Workplace Innovative Orientation. Management Research Review 38: 1126-48. [CrossRef]

Giudici, Alessandro, Yiannis Kouropalatis, and Patrick Reinmoeller. 2016. The Relational Sensing of New Opportunities in Business Matchmaking Events. Academy of Management Proceedings 2016: 17742. [CrossRef]

Grover, Varun, Rahul A. Gokhale, and Ravi S. Narayanswamy. 2009. Resource-Based Framework for IS Research: Knowledge Firms and Sustainability in Knowledge Markets. Journal of the Association for Information Systems 10. [CrossRef] 
Gulati, Shruti. 2021. Decoding the Global Trend of 'Vaccine Tourism' through Public Sentiments and Emotions: Does It Get a Nod on Twitter? Global Knowledge, Memory and Communication. [CrossRef]

Gurbaxani, Vijay, and Debora Dunkle. 2019. Gearing up for Successful Digital Transformation. MIS Quarterly Executive 18. [CrossRef]

Gutierrez-Gutierrez, Leopoldo, and Jiju Antony. 2020. Continuous Improvement Initiatives for Dynamic Capabilities Development: A Systematic Literature Review. International Journal of Lean Six Sigma 11: 125-49. [CrossRef]

Hair, Joe F., Jr., Jörg Henseler, Theo K. Dijkstra, and Marko Sarstedt. 2014a. Common Beliefs and Reality about Partial Least Squares: Comments on Rönkkö and Evermann. Kennesaw: Kennesaw State University.

Hair, Joe F., Jr., Lucy M. Matthews, Ryan L. Matthews, and Marko Sarstedt. 2017. PLS-SEM or CB-SEM: Updated Guidelines on Which Method to Use. International Journal of Multivariate Data Analysis 1: 107-23. [CrossRef]

Hair, Joe F., Jr., Marko Sarstedt, Lucas Hopkins, and Volker G. Kuppelwieser. 2014b. Partial Least Squares Structural Equation Modeling (PLS-SEM). Thousand Oaks: Sage Publisher. [CrossRef]

Hair, Joseph, G. Tomas M. Hult, Christian M. Ringle, and Marko Sarstedt. 2016. A Primer on Partial Least Squares Structural Equation Modeling (PLS-SEM). Thousand Oaks: Sage Publications Ltd.

Hair, Joseph, William Black, Barry Babin, and Rolph Anderson. 2010. Multivariate Data Analysis: A Global Perspective. In Multivariate Data Analysis: A Global Perspective. vol. 7, Available online: https://lib.ugent.be/catalog/rug01:001321386 (accessed on 12 October 2021).

Han, Spring H., Jungwoo Lee, Bo Edvardsson, and Rohit Verma. 2021. Mobile Technology Adoption among Hotels: Managerial Issues and Opportunities. Tourism Management Perspectives 38: 100811. [CrossRef]

Hanchi, Samia El, and Lamia Kerzazi. 2020. Startup Innovation Capability from a Dynamic Capability-Based View: A Literature Review and Conceptual Framework. Journal of Small Business Strategy 30: 72-92.

Hao, Fei, Qu Xiao, and Kaye Chon. 2020. COVID-19 and China's Hotel Industry: Impacts, a Disaster Management Framework, and Post-Pandemic Agenda. International Journal of Hospitality Management 90: 102636. [CrossRef] [PubMed]

Helfat, Constance E., and Margaret A. Peteraf. 2009. Understanding Dynamic Capabilities: Progress along a Developmental Path. Strategic Organization 7: 91-102. [CrossRef]

Henseler, Jörg, Christian M. Ringle, and Marko Sarstedt. 2015. A New Criterion for Assessing Discriminant Validity in Variance-Based Structural Equation Modeling. Journal of the Academy of Marketing Science 43: 115-35. [CrossRef]

Higgins-Desbiolles, Freya, Bobbie Chew Bigby, and Adam Doering. 2021. Socialising Tourism after COVID-19: Reclaiming Tourism as a Social Force? Journal of Tourism Futures. [CrossRef]

Hoskisson, Robert E., Michael A. Hitt, William P. Wan, and Daphne Yiu. 1999. Theory and Research in Strategic Management: Swings of a Pendulum. Journal of Management 25: 417-56. [CrossRef]

Järvenoja, Hanna, Jonna Malmberg, Tiina Törmänen, Kristiina Mänty, Eetu Haataja, Sara Ahola, and Sanna Järvelä. 2020. A Collaborative Learning Design for Promoting and Analyzing Adaptive Motivation and Emotion Regulation in the Science Classroom. Frontiers in Education 5. [CrossRef]

Kandampully, Jay, and Dwi Suhartanto. 2000. Customer Loyalty in the Hotel Industry: The Role of Customer Satisfaction and Image. International Journal of Contemporary Hospitality Management 12: 346-51. [CrossRef]

Karimi-Alaghehband, Forough, and Suzanne Rivard. 2019. Information Technology Outsourcing and Architecture Dynamic Capabilities as Enablers of Organizational Agility. Journal of Information Technology 34: 129-59. [CrossRef]

Kim, Eun A. 2020. Social Distancing and Public Health Guidelines at Workplaces in Korea: Responses to Coronavirus Disease-19. Safety and Health at Work 11: 275-83. [CrossRef]

Kim, Youngbae, and Byungheon Lee. 2002. Patterns of Technological Learning among the Strategic Groups in the Korean Electronic Parts Industry. Research Policy 31: 543-67. [CrossRef]

Kline, Rex B. 1998. Software Review: Software Programs for Structural Equation Modeling: Amos, EQS, and LISREL. Journal of Psychoeducational Assessment 16: 343-64. [CrossRef]

Kock, Ned. 2015. Common Method Bias in PLS-SEM: A Full Collinearity Assessment Approach. International Journal of E-Collaboration 11: 1-10. [CrossRef]

Kump, Barbara, Alexander Engelmann, Alexander Kessler, and Christina Schweiger. 2019. Toward a Dynamic Capabilities Scale: Measuring Organizational Sensing, Seizing, and Transforming Capacities. Industrial and Corporate Change 28: 1149-72. [CrossRef]

Kurniansyah, Firdaus, Erwin Saraswati, and Aulia Fuad Rahman. 2021. "Corporate Governance, Profitability, Media Exposure, and Firm Value: The Mediation Role of Environmental Disclosure". Jurnal Minds: Manajemen Ide Dan Inspirasi 8: 69. [CrossRef]

Lee, Chien Chiang, Godwin Olasehinde-Williams, and Seyi Saint Akadiri. 2021. Geopolitical Risk and Tourism: Evidence from Dynamic Heterogeneous Panel Models. International Journal of Tourism Research 23: 26-38. [CrossRef]

Lee, Seung Hyun, Paul W. Beamish, Ho Uk Lee, and Jong Hun Park. 2009. Strategic Choice during Economic Crisis: Domestic Market Position, Organizational Capabilities and Export Flexibility. Journal of World Business 44: 1-15. [CrossRef]

Ling, Gabriel Hoh Teck, Nur Amiera binti Md Suhud, Pau Chung Leng, Lee Bak Yeo, Chin Tiong Cheng, Mohd Hamdan Haji Ahmad, and Ak Mohd Rafiq Ak Matusin. 2021. Factors Influencing Asia-Pacific Countries' Success Level in Curbing COVID-19: A Review Using a Social-Ecological System (SES) Framework. International Journal of Environmental Research and Public Health 18: 1704. [CrossRef] 
Liu, Chun, and Jingjing Yang. 2021. How Hotels Adjust Technology-Based Strategy to Respond to COVID-19 and Gain Competitive Productivity (CP): Strategic Management Process and Dynamic Capabilities. International Journal of Contemporary Hospitality Management 33: 2907-31. [CrossRef]

Liu, Zheng. 2021. The Impact of Government Policy on Macro Dynamic Innovation of the Creative Industries: Studies of the Uk's and China's Animation Sectors. Journal of Open Innovation: Technology, Market, and Complexity 7: 168. [CrossRef]

Macau, Flavio, Luiz Artur Ledur Brito, and André Luis Castro Moura Duarte. 2016. Effects of Knowledge Development and Culture of Competitiveness on the Performance of Service-Oriented and Product-Oriented Firms. Knowledge and Process Management 23: 219-29. [CrossRef]

Marcel, Salathé, Althaus L. Christian, Neher Richard, Stringhini Silvia, Hodcroft Emma, Fellay Jacques, Zwahlen Marcel, Gabriela Sentif, Manuel Battegayg, Annelies Wilder-Smith, and et al. 2020. COVID-19 Epidemic in Switzerland: On the Importance of Testing, Contact Tracing and Isolation. Swiss Medical Weekly 150: w20225. [CrossRef]

Marhraoui, Mohamed Amine, and Abdellah El Manouar. 2017. IT-Enabled Organizational Agility_Proposition of a New Framework. Journal of Theoretical and Applied Information Technology 95: 5431-42.

Matysiak, Lars, Alan M. Rugman, and Andreas Bausch. 2018. Dynamic Capabilities of Multinational Enterprises: The Dominant Logics Behind Sensing, Seizing, and Transforming Matter! Management International Review 58: 225-50. [CrossRef]

McLaughlin, Stephen A. 2017. Dynamic Capabilities: Taking an Emerging Technology Perspective. International Journal of Manufacturing Technology and Management 31: 62-81. [CrossRef]

Mikalef, Patrick, and Adamantia Pateli. 2017. Information Technology-Enabled Dynamic Capabilities and Their Indirect Effect on Competitive Performance: Findings from PLS-SEM and FsQCA. Journal of Business Research 70: 1-16. [CrossRef]

Mikalef, Patrick, John Krogstie, Ilias O. Pappas, and Paul Pavlou. 2020. Exploring the Relationship between Big Data Analytics Capability and Competitive Performance: The Mediating Roles of Dynamic and Operational Capabilities. Information and Management 57: 103169. [CrossRef]

Mumford, Michael D. 2000. Managing Creative People: Strategies and Tactics for Innovation. Human Resource Management Review 10: 313-51. [CrossRef]

Napierała, Tomasz, Katarzyna Leśniewska-Napierała, and Rafał Burski. 2020. Impact of Geographic Distribution of COVID-19 Cases on Hotels' Performances: Case of Polish Cities. Sustainability 12: 4697. [CrossRef]

Patrício, Vânia, Renato Lopes da Costa, Leandro Pereira, and Nelson António. 2021. Project Management in the Development of Dynamic Capabilities for an Open Innovation Era. Journal of Open Innovation: Technology, Market, and Complexity 7: 164. [CrossRef]

Piening, Erk P., and Torsten Oliver Salge. 2015. Understanding the Antecedents, Contingencies, and Performance Implications of Process Innovation: A Dynamic Capabilities Perspective. Journal of Product Innovation Management 32: 80-97. [CrossRef]

Podsakoff, Philip M., Scott B. MacKenzie, Jeong Yeon Lee, and Nathan P. Podsakoff. 2003. Common Method Biases in Behavioral Research: A Critical Review of the Literature and Recommended Remedies. Journal of Applied Psychology 88: 879. [CrossRef]

Ponciano, Emanuel Soares, and Creusa Sayuri Tahara Amaral. 2021. What Influences the Innovation Environment in BPO Companies? Business Process Management Journal 27: 106-23. [CrossRef]

Porter, Michael E. 1979. Porter 1979 HBR How Competitive Forces Shape Srategy.Pdf. Harvard Business Review. Available online: https:/ / hbr.org/1979/03/how-competitive-forces-shape-strategy (accessed on 10 September 2021).

Powell, Thomas C., and Anne Dent-Micallef. 1997. Information Technology as Competitive Advantage: The Role of Human, Business, and Technology Resources. Strategic Management Journal 18: 375-405. [CrossRef]

Purnomo, Mangku. 2018. Contesting Indonesia's Single Origin Coffee Market: A Dynamic Capabilities Perspective. Asian Social Science 14: 1911-2017. [CrossRef]

Radic, Aleksandar, Rob Law, Michael Lück, Haesang Kang, Antonio Ariza-Montes, Juan M. Arjona-Fuentes, and Heesup Han. 2020. "Apocalypse Now or Overreaction to Coronavirus: The Global Cruise Tourism Industry Crisis". Sustainability 12: 6968. [CrossRef]

Rahma, Valda Shabrina, and Gilang Fadhilia Arvianti. 2020. The Impacts of Covid-19 Pandemic in Indonesia and China'S Hotel Industry: How To Overcome It? Jelajah: Journal Tourism and Hospitality 2: 2020. Available online: https://www.worldometers. info/coronavirus/?\#countries (accessed on 8 October 2021).

Ravichandran, Thiagarajan. 2018. Exploring the Relationships between IT Competence, Innovation Capacity and Organizational Agility. Journal of Strategic Information Systems 27: 22-42. [CrossRef]

Ray, Gautam, Jay B. Barney, and Waleed A. Muhanna. 2004. Capabilities, Business Processes, and Competitive Advantage: Choosing the Dependent Variable in Empirical Tests of the Resource-Based View. Strategic Management Journal 25: 23-37. [CrossRef]

Razak, Norhanim Abdul. 2020. Health and Tourism: Implications of COVID-19 Pandemic to the Malaysian Travel and Hospitality Industry. International Journal of Supply Chain Management 9: 663-70.

Rezazadeh, Bahram, Hadi Karami, and Azhdar Karami. 2016. Technology Orientation, Dynamic Capabilities and SMEs Performance. Strategic Management Quaterly 4: 41-60.

Rialti, Riccardo, Giacomo Marzi, Cristiano Ciappei, and Donatella Busso. 2019. Big Data and Dynamic Capabilities: A Bibliometric Analysis and Systematic Literature Review. Management Decision 57: 2052-68. [CrossRef]

Richtnér, Anders, and Hans Löfsten. 2014. Managing in Turbulence: How the Capacity for Resilience Influences Creativity. $R$ and $D$ Management 44: 137-51. [CrossRef]

Roberts, Nicholas, and Varun Grover. 2012. Leveraging Information Technology Infrastructure to Facilitate a Firm's Customer Agility and Competitive Activity: An Empirical Investigation. Journal of Management Information Systems 28: 231-70. [CrossRef] 
Russell, Robert D., and Craig J. Russell. 1992. An Examination of the Effects of Organizational Norms, Organizational Structure, and Environmental Uncertainty on Entrepreneurial Strategy. Journal of Management 18: 639-56. [CrossRef]

Şahin, Şule, María Del Carmen Boado-Penas, Corina Constantinescu, Julia Eisenberg, Kira Henshaw, Maoqi Hu, Jing Wang, and Wei Zhu. 2020. First Quarter Chronicle of Covid-19: An Attempt to Measure Governments' Responses. Risks 8: 115. [CrossRef]

Al Saidi, Ahmed Mohammed Obaid, Fowsiya Abikar Nur, Ahmed Salim Al-Mandhari, Maha El Rabbat, Assad Hafeez, and Abdinasir Abubakar. 2020. Decisive Leadership Is a Necessity in the COVID-19 Response. The Lancet 396: 295. [CrossRef]

Sallam, Malik, Deema Dababseh, Huda Eid, Kholoud Al-Mahzoum, Ayat Al-Haidar, Duaa Taim, Alaa Yaseen, Nidaa A. Ababneh, Faris G. Bakri, and Azmi Mahafzah. 2021. High Rates of Covid-19 Vaccine Hesitancy and Its Association with Conspiracy Beliefs: A Study in Jordan and Kuwait among Other Arab Countries. Vaccines 9: 42. [CrossRef]

Schnellbächer, Benedikt, and Sven Heidenreich. 2020. The Role of Individual Ambidexterity for Organizational Performance: Examining Effects of Ambidextrous Knowledge Seeking and Offering. Journal of Technology Transfer 45: 1535-61. [CrossRef]

Schuberth, Florian, Jörg Henseler, and Theo K. Dijkstra. 2018. Confirmatory Composite Analysis. Frontiers in Psychology. [CrossRef]

Schweitzer, Fiona M., Oliver Gassmann, and Kurt Gaubinger. 2011. Open Innovation and Its Effectiveness to Embrace Turbulent Environments. In International Journal of Innovation Management 15: 1191-1207. [CrossRef]

Scuotto, Veronica, Gabriele Santoro, Stefano Bresciani, and Manlio Del Giudice. 2017. Shifting Intra- and Inter-Organizational Innovation Processes towards Digital Business: An Empirical Analysis of SMEs. Creativity and Innovation Management 26: 247-55. [CrossRef]

Seo, Kwanglim, Linda Woo, Sung Gyun Mun, and Jungtae Soh. 2021. The Asset-Light Business Model and Firm Performance in Complex and Dynamic Environments: The Dynamic Capabilities View. Tourism Management 85: 104311. [CrossRef]

Singh, Manjari, and Anita Sarkar. 2019. Role of Psychological Empowerment in the Relationship between Structural Empowerment and Innovative Behavior. Management Research Review 42: 521-38. [CrossRef]

Škare, Marinko, Domingo Riberio Soriano, and Małgorzata Porada-Rochon. 2021. Impact of COVID-19 on the Travel and Tourism Industry. Technological Forecasting and Social Change 163: 120469. [CrossRef]

Smart, Denise T., and Jeffrey S. Conant. 2011. Entrepreneurial Orientation, Distinctive Marketing Competencies And Organizational Performance. Journal of Applied Business Research (JABR) 10: 28. [CrossRef]

Smith, Maxwell J. 2021. What Constitutes Success in the Roll-out of COVID-19 Vaccines? The Lancet 398: 115-16. [CrossRef]

Soto-Acosta, Pedro, Simona Popa, and Daniel Palacios-Marqués. 2016. E-Business, Organizational Innovation and Firm Performance in Manufacturing SMEs: An Empirical Study in Spain. Technological and Economic Development of Economy 22: 885-904. [CrossRef]

Stehn, Lars, Susanne Engström, Petri Uusitalo, and Rita Lavikka. 2021. Understanding Industrialised House Building as a Company's Dynamic Capabilities. Construction Innovation 21: 5-21. [CrossRef]

Suddaby, Roy, William M. Foster, and Chris Quinn Trank. 2010. Rhetorical History as a Source of Competitive Advantage. Advances in Strategic Management 27: 147-73. [CrossRef]

Sürücü, Özlem, Yüksel Öztürk, Fevzi Okumus, and Anil Bilgihan. 2019. Brand Awareness, Image, Physical Quality and Employee Behavior as Building Blocks of Customer-Based Brand Equity: Consequences in the Hotel Context. Journal of Hospitality and Tourism Management 40: 114-24. [CrossRef]

Taber, Keith S. 2018. The Use of Cronbach's Alpha When Developing and Reporting Research Instruments in Science Education. Research in Science Education 48: 1273-96. [CrossRef]

Talafidaryani, Mojtaba. 2021. A Text Mining-Based Review of the Literature on Dynamic Capabilities Perspective in Information Systems Research. Management Research Review 44: 234-67. [CrossRef]

Tavitiyaman, Pimtong, Xinyan Zhang, and Wing Yin Tsang. 2020. How Tourists Perceive the Usefulness of Technology Adoption in Hotels: Interaction Effect of Past Experience and Education Level. Journal of China Tourism Research, 1-24. [CrossRef]

Teece, David J., Gary Pisano, and Amy Shuen. 1997. Dynamic Capabilities and Strategic Management. Strategic Management Journal 18: 509-33. [CrossRef]

van der Voordt, D. J. M. 2003. Costs and Benefits of Innovative Workplace Design. Facilities 22. Available online: https://research. tudelft.nl/en/publications/costs-and-benefits-of-innovative-workplace-design (accessed on 10 September 2021).

Villalobos, J. René, Wladimir E. Soto-Silva, Marcela C. González-Araya, and Rosa G. González-Ramirez. 2019. Research Directions in Technology Development to Support Real-Time Decisions of Fresh Produce Logistics: A Review and Research Agenda. Computers and Electronics in Agriculture 167: 105092. [CrossRef]

Wai Lai, Ivan Ka. 2019. Hotel Image and Reputation on Building Customer Loyalty: An Empirical Study in Macau. Journal of Hospitality and Tourism Management 38: 111-21. [CrossRef]

Wernerfelt, Birger. 1984. A Resource-based View of the Firm. Strategic Management Journal 5: 171-80. [CrossRef]

Williams, Nigel L., Thi Hong Hai Nguyen, Giacomo Del Chiappa, Giancarlo Fedeli, and Philipp Wassler. 2021. COVID-19 Vaccine Confidence and Tourism at the Early Stage of a Voluntary Mass Vaccination Campaign: A PMT Segmentation Analysis. Current Issues in Tourism, 1-15. [CrossRef]

Wu, Lei Yu. 2007. Entrepreneurial Resources, Dynamic Capabilities and Start-up Performance of Taiwan's High-Tech Firms. Journal of Business Research 60: 549-55. [CrossRef]

Zahra, Shaker A., Harry J. Sapienza, and Per Davidsson. 2006. Entrepreneurship and Dynamic Capabilities: A Review, Model and Research Agenda. Journal of Management Studies 43: 917-55. [CrossRef] 
Zhang, Yali, Jun Sun, Zhaojun Yang, and Ying Wang. 2020. Critical Success Factors of Green Innovation: Technology, Organization and Environment Readiness. Journal of Cleaner Production 264: 121701. [CrossRef]

Zhou, Steven S., Abby J. Zhou, Junzheng Feng, and Shisong Jiang. 2019. Dynamic Capabilities and Organizational Performance: The Mediating Role of Innovation. Journal of Management and Organization 25: 731-47. [CrossRef]

Zhou, Zhao, and Robert Verburg. 2020. Open for Business: The Impact of Creative Team Environment and Innovative Behaviour in Technology-Based Start-Ups. International Small Business Journal: Researching Entrepreneurship 38: 318-36. [CrossRef]

Ziyae, Babak, Hossein Sadeghi, and Maryam Golmohammadi. 2021. Service Innovation in the Hotel Industry: The Dynamic Capabilities View. Journal of Enterprising Communities. [CrossRef]

Zollo, Maurizio, and Sidney G. Winter. 2002. Deliberate Learning and the Evolution of Dynamic Capabilities. Organization Science 13: 339-51. [CrossRef] 